Article

\title{
Carbon as Investment Risk-The Influence of Fossil Fuel Divestment on Decision Making at Germany's Main Power Providers
}

\section{Dagmar Kiyar ${ }^{1, *}$ and Bettina B. F. Wittneben ${ }^{2,3}$}

1 Wuppertal Institute for Climate, Environment and Energy, Döppersberg 19, 42103 Wuppertal, Germany

2 Environmental Change Institute, School of Geography and the Environment, University of Oxford, Oxford OX1 3QY, UK; E-Mail: bettina.wittneben@smithschool.ox.ac.uk

3 Pentland Centre for Sustainability in Business, Lancaster University, Lancaster LA1 4YX, UK

* Author to whom correspondence should be addressed; E-Mail: dagmar.kiyar@wupperinst.org; Tel.: +49-202-2492-233; Fax: +49-202-2492-250.

Academic Editor: Vincenzo Dovì

Received: 4 June 2015 / Accepted: 19 August 2015 / Published: 3 September 2015

\begin{abstract}
German electricity giants have recently taken high-level decisions to remove selected fossil fuel operations from their company portfolio. This new corporate strategy could be seen as a direct response to the growing global influence of the fossil fuel divestment campaign. In this paper we ask whether the divestment movement currently exerts significant influence on decision-making at the top four German energy giants-E.On, RWE, Vattenfall and EnBW. We find that this is not yet the case. After describing the trajectory of the global fossil fuel divestment campaign, we outline four alternative influences on corporate strategy that, currently, are having a greater impact than the divestment movement on Germany's power sector. In time, however, clear political decisions and strong civil support may increase the significance of climate change concerns in the strategic management of the German electricity giants.
\end{abstract}

Keywords: carbon management; fossil fuel divestment; strategic decision-making; sustainability investment; stranded assets; German power sector; carbon budget 


\section{Introduction}

In late 2014, at the time of the Lima Climate Summit, Germany's largest electricity provider, E.ON, surprised the financial world with the spectacular announcement that the company would shed all of its nuclear and fossil fuel assets and focus exclusively on renewable energy generation. To do so, company activities will be split into two independent entities. From 2016, E.ON's fossil fuel and nuclear generation will be carried out by a new company called Uniper, while the original E.ON will concentrate on renewables, electricity distribution networks and customer service [1].

This announcement shows that the once so successful business model of Germany's electricity giants is becoming increasingly outdated. Pressure from the government's energy transition policy, the German Energiewende, has had a drastic effect on company strategy and finance. This policy renders nuclear power in Germany obsolete by 2022 and, more recently, has become a challenge for energy production from coal. This latest initiative has prompted a discussion on reducing emissions from the energy sector by 22 million tonnes of $\mathrm{CO}_{2}$ by 2020 , which is equivalent to shutting down about eight coal-fired power plants [2]. Furthermore, in order to reach its Energiewende and climate objectives, the German government has set several targets that should guide climate and energy policies up until 2050. By 2020, Germany is aiming to cut greenhouse gas emissions by $40 \%$ compared to 1990 levels, which means a reduction of about $500 \mathrm{Mt} \mathrm{CO} 2$. Between 1990 and 2014, Germany reduced emissions by about $24.7 \%$ [2]. However, given that over the past two years emissions have actually increased, the government plans to implement additional measures such as a climate levy.

As German energy giants have come under pressure from the government, the international financial sector has become increasingly concerned about a potential carbon bubble. This phenomenon is based on the notion that if the $2{ }^{\circ} \mathrm{C}$ global warming target is taken seriously by international politicians, "no more than one-third of proven reserves of fossil fuels can be consumed prior to 2050" [3]. This means leaving one third of proven global oil reserves, half of the gas reserves and some eighty per cent of coal reserves in the ground between 2010 and 2050 [4]. As a result, a large amount of fossil fuel companies' assets would be 'stranded' and these companies would be considered over-valued.

In this context, a recently published report from the Carbon Disclosure Project (CDP) analysed sixteen European electricity companies to assess their future low-carbon potential. The ranking focused on four key areas: carbon risk, renewable energy sources, coal exposure and water risk. The German companies noted above were rated poorly, with E.ON ranked nine, EnBW ranked 12 and RWE ranked 13 (Vattenfall was not included). The main reason for their poor performance was their high dependence on coal reserves and therefore high carbon cost exposure: a carbon price rising to 18 Euros would make these companies extremely vulnerable, the report stated. Based on their Earnings Before Interest and Taxes (EBIT) in 2013, 43\% of RWE's earnings would be at risk, followed by EnBW (28\%) and E.ON (18\%). The CDP report argued that with climate policies becoming stricter, carbon costs would increase, causing these companies to become an investment risk [5].

The fossil fuel divestment campaign has emerged as an attempt to convince investors to rid themselves of fossil fuel-based company shares in their portfolios. This has led to company business models being questioned and branded unsustainable. 
Given the most recent announcements by German energy giants to rid themselves of carbon assets, we ask the research question: are key strategic decisions at the four largest German energy companies being influenced by the global fossil fuel divestment campaign? Our answer is: "not quite yet".

Beginning with a methodology section showing that we base our insights on qualitative data collected through interviews and participatory observation as well as publicly available statistical data, we present a short overview of the fossil fuel divestment campaign in our findings section. We then illustrate that four factors other than the divestment campaign are having greater influence on the top level strategic management decisions at German energy giants. Our conclusions summarise our findings and suggest that while the influence of the campaign on German electricity companies may be less noticeable than in other countries, there is evidence that this could change in the future.

\section{Methodology}

The findings presented in this paper are based on the triangulation of data. We used primary data from expert interviews and participatory observations at two official company events to deepen our understanding of the general attitudes that prevail at the examined companies. We used secondary data provided by companies and government sources to underpin our arguments. In terms of the latter data, we extracted relevant figures and statistics directly from annual reports, official sustainability reports and government data. These are featured in the paper.

The qualitative data collection took place over two years and enabled us to gain an insight into decision making at the strategic level at the four German energy giants. The empirical work was carried out in three phases. Firstly, a desk review study of official company communication was conducted to establish the development of climate policy at the four companies and the companies' relationships with external stakeholders. Secondly, a pilot of three interviews was completed, to refine the questionnaire, gain a better understanding of the German electricity market and prepare for the analysis of the expert interviews. Finally, seven expert interviews with representatives from the four companies were conducted between August and October 2011. The interviews were on average 60 minutes long, were fully transcribed and analysed using a summarising qualitative content analysis. They covered the political situation in Germany, including the effects of the Energiewende and the government's promotion of renewable energy, and climate policy issues within the company. All interviews and the participatory observation were led by the first author of this paper. Much of the qualitative data forming the basis of this paper was published in an earlier, extensive study of corporate climate policy but is available in German only [6].

\section{Findings}

\subsection{The Fossil Fuel Divestment Campaign}

Over the past months and recent years, several organisations, such as fossilfreeindexes.com, the Carbon Tracker Initiative and the Stranded Assets Programme at the University of Oxford's Smith School of Enterprise and the Environment, have analysed the financial risk of fossil fuel companies. A social movement called the fossil fuel divestment campaign has been encouraging institutional and private investors to sell shares in companies that use fossil fuels in their energy or industrial 
production. Investors at universities and churches have been at the forefront of the campaign and now, this is becoming increasingly prominent among investment funds and banks. Table 1 shows examples of institutions reacting to this call for divestment.

Table 1. Examples of institutions implementing fossil fuel divestment [7-9].

\begin{tabular}{|c|c|c|c|}
\hline Institution & Year & $\begin{array}{l}\text { Amount } \\
\text { Divested }\end{array}$ & Action \\
\hline $\begin{array}{c}\text { University of } \\
\text { Stanford }\end{array}$ & 2014 & $\begin{array}{c}\text { \$21.4bn } \\
\text { endowment }\end{array}$ & $\begin{array}{l}\text { After a petition by the student-led organisation 'Fossil } \\
\text { Free Stanford' and the recommendation of Stanford's } \\
\text { Advisory Panel on Investment Responsibility and } \\
\text { Licensing (APIRL), the Stanford Board of Trustees decide } \\
\text { against direct investments in coal mining companies }\end{array}$ \\
\hline $\begin{array}{l}\text { Rockefeller } \\
\text { Brothers Fund }\end{array}$ & 2014 & $\$ 50 \mathrm{bn}$ & $\begin{array}{l}\text { - In September 2014, the heirs to the Standard Oil fortune join } \\
\text { the campaign and divest a total of } \$ 50 \mathrm{bn} \text { from fossil fuels }\end{array}$ \\
\hline $\begin{array}{c}\text { The Bank of } \\
\text { England }\end{array}$ & 2015 & - & $\begin{array}{l}\text { - Warns insurance companies of "assets that could be left } \\
\text { 'stranded' by policy changes which limit the use of fossil } \\
\text { fuels" [7] }\end{array}$ \\
\hline $\begin{array}{c}\text { The Church of } \\
\text { England }\end{array}$ & 2015 & $\begin{array}{l}£ 9 \text { bn fund } \\
\text { (to divest } \\
£ 12 \mathrm{~m} \text { from tar } \\
\text { sands oil and } \\
\text { thermal coal) }\end{array}$ & $\begin{array}{l}\text { - In May } 2015 \text {, the Church of England announces, that it } \\
\text { will divest its holdings of } £ 12 \mathrm{~m} \text { in thermal coal and tar } \\
\text { sands. The Church bans investments in any company that } \\
\text { make more than } 10 \% \text { of their revenue from thermal coal } \\
\text { and tar sands }\end{array}$ \\
\hline $\begin{array}{c}\text { Norway's } \\
\text { Sovereign } \\
\text { Wealth Fund }\end{array}$ & 2015 & $\begin{array}{l}\text { Worth an } \\
\text { estimated } \\
\text { \$850bn; Coal } \\
\text { divestment: } \\
\text { about } \$ 4.5 b n \\
\text { is being } \\
\text { discussed }\end{array}$ & $\begin{array}{l}\text { - The } \$ 900 \text {-billion fund does not officially affiliate with the } \\
\text { campaign } \\
\text { - Nevertheless, the fund establishes higher climate change } \\
\text { standards for companies in which it invests, and divests } \\
\text { from more than } 100 \text { companies with unsustainable } \\
\text { business models [8] } \\
\text { May 2015: announces that it will divest from companies } \\
\text { which generate more than } 30 \% \text { of their revenue from coal }\end{array}$ \\
\hline HSBC & 2015 & - & $\begin{array}{l}\text { - Analyses the risks of stranded assets and concludes that } \\
\text { due to climate change regulation, as well as technological } \\
\text { advancements and innovations in efficiency, the energy } \\
\text { mix is expected to alter in the coming years, "potentially } \\
\text { resulting in further stranding of high carbon and high cost } \\
\text { fossil fuels" [9] } \\
\text { - Coal assets form the highest risk as they face greater } \\
\text { regulatory risks, high emissions and substitution } \\
\text { possibilities [9] }\end{array}$ \\
\hline
\end{tabular}

The movement originated with a call by Bill McKibben of the 350.org project, published in Rolling Stone Magazine, to divest from fossil fuels. His 2012 article [10] argued that at current levels of fossil fuel extraction, the human race will face hardship as the climate becomes unpredictable and irregular. He asserted that carbon emissions from all known fossil fuel reserves about to be exploited would play havoc with the climate. McKibben subsequently founded the fossil fuel divestment campaign, which has become highly vocal in encouraging private and institutional investors to divest. Although it may 
not yet be influencing companies directly, the naming and shaming of oil, gas and coal-based businesses is stigmatising these firms. This could adversely affect their lending rates and political influence [11].

This fossil fuel divestment campaign has since received support from the United Nations climate secretariat [12]. The United Nations Secretary-General Ban Ki-moon declared at a press conference: "I have been urging companies like pension funds or insurance companies to reduce their investments in coal and a fossil-fuel based economy to move to renewable sources of energy." [13].

Critics, however, claim that divestment campaigns, like the one described above or the Guardian newspaper's 'Leave it in the Ground' initiative, may be doing more harm than good. Critical voices [14] note that shareholders, as the owners of companies, have the power to influence the management of these firms. In other words, investment equals control. Divestment campaigns therefore "turn an inside voice that can demand that a company listen into an outside voice that a company can easily ignore" [14]. Furthermore, Devinney [14] points out that divestment has no influence on the ability to invest, as the shares that are sold do not affect a company's cash flow.

\subsection{The Campaign's Influence on Germany's Electricity Sector}

For a long time, the majority of Germany's power sector, or more precisely, Germany's four biggest power companies, relied on gas and particularly on coal. Two of the companies (RWE and Vattenfall) relied heavily on lignite, the most $\mathrm{CO}_{2}$-intensive fossil fuel, to help fulfil Germany's energy demand. To counterbalance their carbon account, these companies have recently based a significant part of their portfolio on nuclear energy and have slowly started investing in renewables. In the recent past, Carbon Capture and Storage (CCS) technology used to also be an important technology option for the four companies, to reduce their $\mathrm{CO}_{2}$ emissions without giving up fossil fuels. However, the future of this technology in Germany is now doubtful (for more information on CCS in Germany, see e.g., [15,16]) and, in light of the German energy transition, nuclear energy is no longer an option: The remaining nuclear power plants will be phased out by 2022 .

German electricity giants have recently taken high-level decisions to remove selected fossil fuel operations from their portfolio of company activity. This corporate strategy could be a response to the growing global influence of the fossil fuel divestment campaign. We find, though, that the following reasons are more plausible in explaining this situation and why, at the moment, the influence of the campaign might not be as strong as it is in other Western countries.

\section{Discussion}

The four companies examined here have recently taken high-level decisions to remove selected fossil fuel operations from their portfolio of company activity. We summarise implemented and scheduled plans briefly in Table 2 .

These developments could be attributed to the divestment campaign, as they seem to be in line with the campaign's aims. However, we find that four alternative factors, which we call 'influencers', have had more impact on company decision making than the fossil fuel divestment campaign. 
Table 2. The four companies' decisions to remove selected fossil fuel operations from their portfolio $[17,18]$.

\begin{tabular}{|c|c|}
\hline Company & Decisions \\
\hline E.ON & $\begin{array}{l}\text { - Plans to spin-off its fossil fuel and nuclear generation business in } 2016 \text { to a new } \\
\text { company, Uniper } \\
\text { - Focuses on renewables, electricity distribution networks and service for } \\
\text { customers under the E.ON brand }\end{array}$ \\
\hline RWE & $\begin{array}{l}\text { - Decommissions several power stations (e.g., Goldenbergwerk, Westfalen C and } \\
\text { Gersteinwerk K2) } \\
\text { - Initiates the long-term mothballing of others (e.g. Gersteinwerk F+G and } \\
\text { Weisweiler G+H) } \\
\text { - Resolves several divestment decisions (selling off district heating sector of } \\
\text { Essent, RWE's Dutch subsidiary, and RWE-DEA, the gas and crude oil } \\
\text { production subsidiary) }\end{array}$ \\
\hline Vattenfall & $\begin{array}{l}\text { - Plans to sell the lignite generation plants and mines in eastern Germany } \\
\text { - Has already divested in a number of operations, such as its heat and electricity } \\
\text { network businesses in Poland and Finland }\end{array}$ \\
\hline EnBW & $\begin{array}{l}\text { - Expands its divestiture programme to a total of } € 2.6 \text { billion for the period from } \\
2013 \text { to } 2015 \\
\text { - Plans to shut down } 686 \mathrm{MW} \text { in fossil power plants in Southern Germany } \\
\text { (Marbach and Walheim) (As those power plants are deemed "system-relevant", } \\
\text { the German Federal Network Agency (BNetzA) has prohibited their } \\
\text { decommissioning until 2016) }\end{array}$ \\
\hline
\end{tabular}

\section{Influencer 1: Electricity Prices}

Several considerations have prompted these shifts in the business strategies of the four companies, with the drop in electricity prices and subsequent fall in profit margins likely to be the primary driver. The rising share of renewable energies, illustrated in Figure 1, puts wholesale electricity prices under pressure, as the so-called merit order, which represents marginal supply costs of different technologies, is shifted to the right [19].

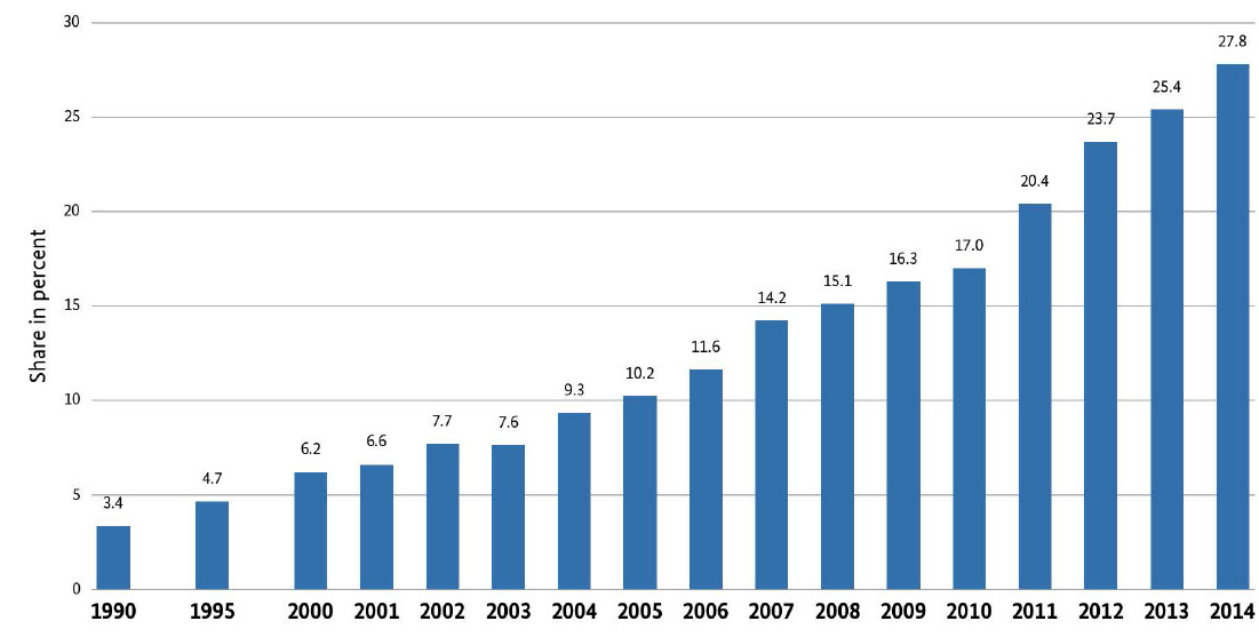

Figure 1. Development of renewable energy share of gross electricity consumption in Germany [20]. 
A study by Germany's Institute for Future Energy Systems (IZES), on behalf of the German Solar Industry Association (BSW-Solar), found that prices dropped despite power demand remaining unchanged. Furthermore, there was an observable alignment between the peak and base price, which used to be 20 to $25 \%$ apart. This was a direct result of the instalment of photovoltaic panels which led to a reduction of the electricity price on the power exchange by 520 to 840 million Euro [21]. Figure 2 shows the overall development of the day-ahead price at the German power exchange between 2002 and 2014.

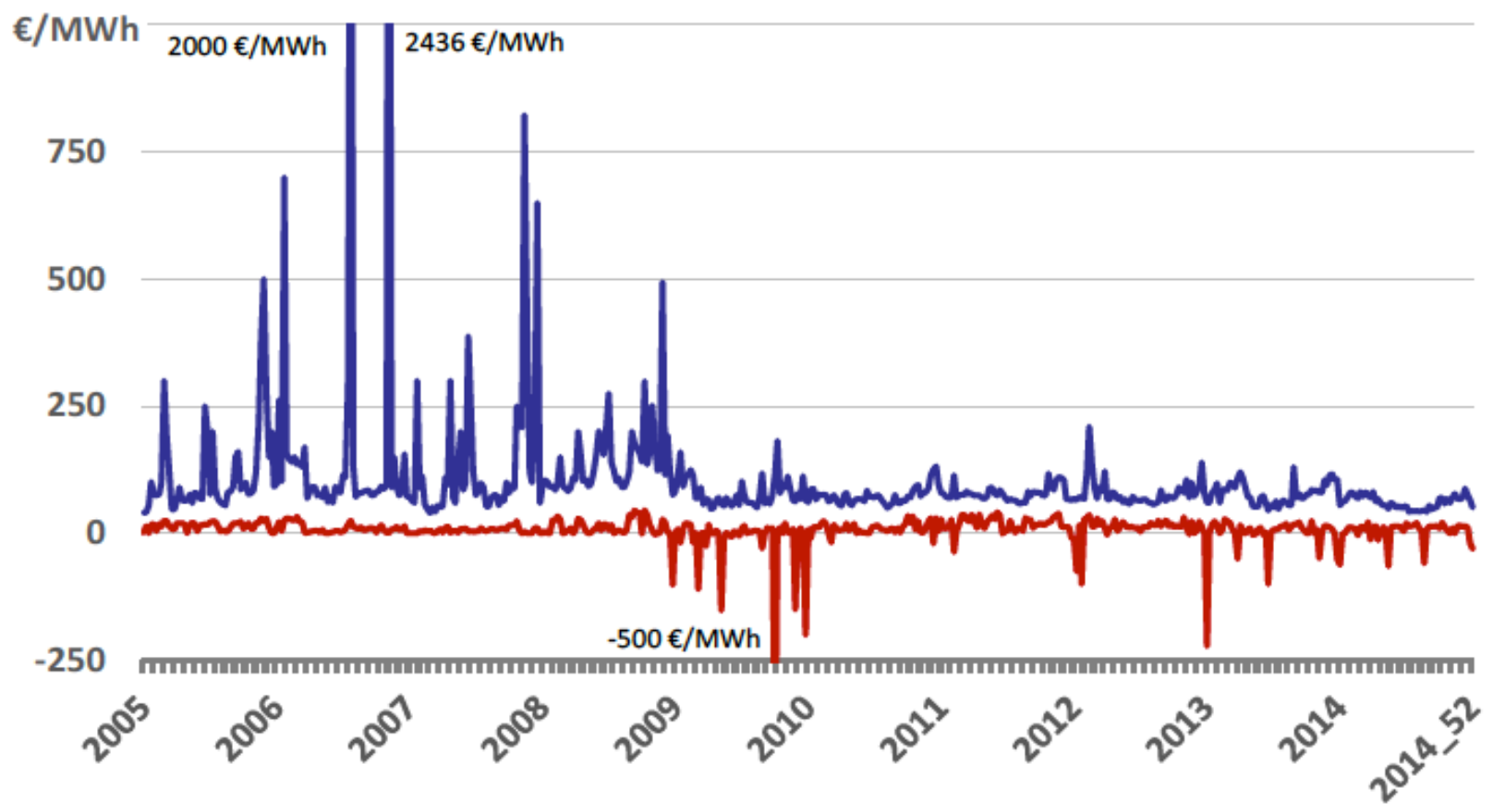

Figure 2. Weekly Day-Ahead maximum and minimum prices, Update: December 2014 [22].

Occasionally, the European Energy Exchange (EEX) even shows negative prices in times of low demand, reflecting high amounts of inflexible power generation, which cannot be shut down and restarted in a timely manner or at reasonable cost. "Frequent occurrences of negative prices in many European markets signal the need for better integration of renewables into the power grid. On a Sunday afternoon in mid-June wind and solar assured more than $60 \%$ of power generation in Germany, resulting in negative hourly prices in the whole CWE region" [23].

The Fraunhofer ISE Institute revealed that in Germany, hours with low prices $(<10 € / \mathrm{MWh})$ quadrupled between the first half of 2013 compared to the first half of 2012, and that hours with negative prices have risen by nearly $50 \%$ [24]. They conclude that more flexibility is needed in the conventional power plant complex for a successful energy transition.

As a consequence of this trend, these companies have been, and are still, losing money from the operation of their conventional power plants. The new challenges, accompanied by the high percentage of fluctuating energy sources, demand new business models and strategies (key words are smart grids, load or demand-side management and electricity storage, as well as highly flexible fossil-fuel reserve power). Critics often blame high renewable subsidies for overcapacity in the market and decreasing electricity prices. A recent working paper from the IMF, however, puts this argument in perspective, showing that fossil fuels are actually subsidised by a stunning $\$ 5.3 \mathrm{tn}$. This dwarfs global 
renewable energy subsidies, which are estimated at $\$ 120 \mathrm{bn}$ [25]. In fact, the IMF notes that the abolition of fossil fuel subsidies globally would reduce $\mathrm{CO}_{2}$ emissions by more than 20\% [26]. In Germany, subsidies for energy supply and consumption amounted to $€ 21.6 \mathrm{bn}$ in 2010 . The German Umweltbundesamt, the federal environmental agency, which provided these figures, points out that as these subsidies have a market-distorting effect, they simultaneously increase the need for renewable energy funding [27]. In Germany, renewable energies especially benefit through the German Renewable Energy Sources Act which provides remuneration not as a subsidy as such because it is not financed by taxes. Instead it is paid by every customer through a Renewable Energy Sources Act EEG surcharge, which is included in the electricity bill (in 2014: $6.24 \mathrm{ct} / \mathrm{kWh}$, in 2015: $6.17 \mathrm{ct} / \mathrm{kWh}$ ) [28].

\section{Influencer 2: Company Ownership}

The carbon divestment campaign mainly focuses on publicly listed companies but of the four companies examined here, only two, RWE and E.ON, are publicly listed and affected by the campaign. EnBW is de facto publicly listed, but the equity is actually divided between NECKARPRI Beteiligungsgesellschaft $\mathrm{mbH}(46.75 \%$ of the shares), which is $100 \%$ owned by the state of Baden-Württemberg (in south-west Germany) and OEW Energie-Beteiligungs $\mathrm{GmbH}(46.75 \%$ of the shares), a coalition of regional corporations and municipalities. EnBW holds about $2 \%$ of its own shares.

A closer look at the privately owned companies, EnBW and Vattenfall, shows that their business decisions seem to be in line with the divestment campaign's aim: Vattenfall is planning to sell its lignite generation plants and mines in eastern Germany, and EnBW has expanded its divestiture programme to a total of $€ 2.6$ billion for the period from 2013 to 2015 . EnBW is also planning to shut down fossil fuel power plants. The reasons behind these companies' decisions are generally accepted to be government policy-related. The green-red coalition in the federal state of Baden-Württemberg is the driver for EnBW's change of course and the Swedish government, which owns Vattenfall AB, has prompted Vattenfall's restructuring plans.

\section{Influencer 3: Government Regulation}

Electricity generation is a highly regulated policy field in Germany. The federal government has mapped out its Energy Policy up to the year 2050 very precisely as can be seen in Figure 3:

Figure 3 shows that by 2020 renewables are to have a share of at least $35 \%$ in gross electricity consumption, a $50 \%$ share by $2030,65 \%$ by 2040 and $80 \%$ by 2050 . For gross final energy consumption, the targets are $18 \%$ by 2020 , a $30 \%$ share by $2030,45 \%$ by 2040 and $60 \%$ by 2050 . Compared to 2008 , heat demand in buildings is to be reduced by $20 \%$ by 2020 , while primary energy demand is to fall by $80 \%$ by 2050 . For greenhouse gases, a reduction of $80 \%$ until 2050 is the target. 


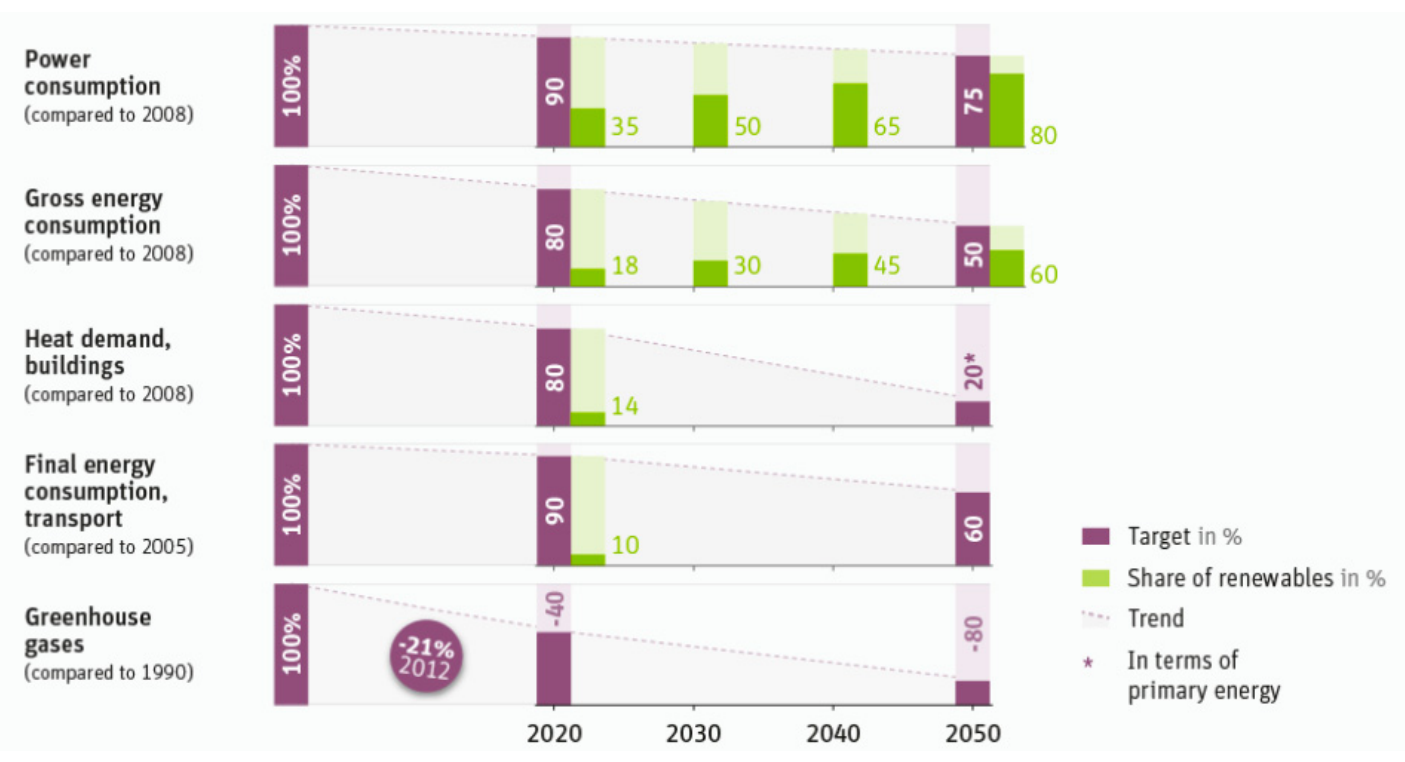

Figure 3. Long-term, comprehensive energy and climate targets set by the German government in 2010 [29].

Renewables have formed an important part of German energy policies for more than two decades. In 1991, Germany enacted the Grid Feed-In Law (German: Stromeinspeisungsgesetz, StromEinspG) obliging energy companies to purchase electricity from renewable energy sources at minimum prices. This law was replaced by the Renewable Energy Sources Act (German: Erneuerbare-Energien-Gesetz, EEG) in 2000, which aimed to increase the share of renewable energies in German electricity generation. The EEG was amended and revised in the years 2004, 2009, 2012 and 2014. The revised version of the EEG is a crucial part of the German energy transition, as it "aims to substantially slow any further rise in costs, to systematically steer the expansion of renewable energy, and to bring renewable energy more and more to the market" [30].

Under this energy policy, the four large German electricity companies have had to reinvent their portfolio of activities as their nuclear assets and high shares of coal generation are incompatible with the political vision. This is unlike the UK, that introduced a capacity market system, where a payment is provided not only for electricity generation, but for the provision of reliable sources of capacity [31]. Such a model is unlikely to be introduced in Germany, as "overcapacities currently amount to roughly 60 gigawatts in the electricity market region relevant for Germany" [32] — largely due to the rising share of renewable energies. The share of nuclear energy in the gross electricity production has already decreased from 22.2\% (before Fukushima) to 15.8\%. Over the same period (2010 to 2014) the share of renewables has increased from $16.6 \%$ to $26.2 \%$ [33].

Although the capacity market is discussed in the Green Paper “An Electricity Market for Germany's Energy Transition" the option "Electricity Market 2.0", an optimised electricity market that provides enough incentive for the maintenance of sufficient capacity is favoured. "According to scientific studies, an optimised electricity market that allows undistorted price signals to reach market participants, and is safeguarded by a credible legal framework, is possible without an additional capacity market" [32]. In such a market the state is responsible for setting market rules: "through their specific demand, the electricity customers are independently responsible for determining the capacity level" [32]. 
With this amount of overcapacity, electricity companies lose their negotiation tactic of threatening governments with withholding investments in the energy infrastructure.

Policy is an important stakeholder of the company, but the owner or shareholder of a company still plays a significant role in business decisions. "Climate change has become one of the most financially significant environmental concerns facing investors" [34]. This is especially true for the electricity sector because the investment pressure on companies "is increasing as investors express their concerns about regulatory uncertainty and price volatility facing the industry" [34]. Roosevelt/Llewelyn point out that in recent years, investors have been the first to see the opportunities of a new environmental era and were among the first to invest in sustainable energy companies [35]. This trend is likely to continue: "As resource limitations, especially related to fossil fuels, increasingly impinge on corporate performance, more investors will include a company's environmental strategy as a variable in their analysis [36].

Concerning shareholder involvement in business strategies-the inside voice as Devinney frames it [14]-there are certainly institutional investors using their voice to demand sustainable business decisions [37,38]. Schmidt/Speich reveal that at RWE's 2009 general meeting, activist shareholders warned the company of the financial liability of emissions trading and of the high financial risk of involvement in Eastern European nuclear power plants like Belene.

However, it remains to be seen whether their influence is sufficient to bring about major changes, such as a complete fossil fuel phase-out. A gradually greener investment and alignment may be the result of shareholder activism, but a majority of shareholders might not support drastic changes in the business model of their company. This is especially true for a company like RWE, where municipalities are the largest single shareholder with more than 15\% [39]. Municipalities depend heavily on annual dividends. Nevertheless, the questioning of the business model of electricity companies by an important shareholder like the Norwegian sovereign wealth fund might influence and impact other funds as well [40].

\section{Influencer 4: Domestic Energy Sources}

Through the Energiewende, the German government decided to abandon nuclear energy while maintaining high industrial output. The renunciation of coal, as proposed by the divestment campaign and parts of the German policy with view to national climate targets, faces a strong pro-coal lobby. Renewable energies amount to a quarter of Germany's gross electricity consumption yet lignite continues to be referred to as the only remaining domestic energy source in Germany. There are two large lignite deposits in the Rhineland (RWE) and in Lusatia (Vattenfall). Associated with this perspective is the national energy security agenda, as an energy self-sufficient Germany will generate jobs and wealth especially in regions that already face economic decline. Opponents of coal are facing powerful and diversified coal advocates, including not only the electricity companies, but also unions, local politicians and concerned citizens.

Lignite is the most important fossil fuel domestic energy source. The strong global coal lobby becomes even more vocal when political plans challenge lignite as a power source, just as it does when a potential climate levy for old coal-fired power stations is discussed. RWE's CEO Peter Terium predicted that this proposal "will introduce a total exit from lignite in the short run. Not only power plants, but also the associated open-cast mines and operations, would need to be closed down." As a result, "restructuring costs for the companies affected would run into the billions" [41]. A study 
commissioned by DEBRIV, the German association of all lignite producing companies and their affiliated organisations, found that that 40,000 jobs could be at risk if coal was phased out in Germany [42].

One reason behind the idea of a climate levy on coal is the high specific emission factor of lignite, which is listed in Table 3.

Table 3. Fossil fuel $\mathrm{CO}_{2}$ emission factor in the German electricity mix [43].

\begin{tabular}{ccccc}
\hline FUEL/UNIT & $\begin{array}{c}\mathbf{C O}_{2} \text { Emission } \\
\text { Factor Related } \\
\text { to Fuel Input } \\
(\mathbf{g} / \mathbf{k W h})\end{array}$ & $\begin{array}{c}\text { Fuel Utilisation Rate } \\
\text { in 2011 Related to } \\
\text { Electricity } \\
\text { Consumption }(\%)\end{array}$ & $\begin{array}{c}\mathbf{C O}_{2} \text { Emission Factor } \\
\text { in 2011 Related to } \\
\text { Electricity } \\
\text { Consumption }(\mathbf{g} / \mathbf{k W h})\end{array}$ & $\begin{array}{c}\text { Comparison } \mathbf{C O}_{2} \\
\text { Emission Factor } \\
\text { Electricity Mix } \\
\mathbf{2 0 1 1}(\mathbf{g} / \mathbf{k W h})\end{array}$ \\
\hline Gas & 202 & $52 \%$ & 388 & \\
Hard Coal & 339 & $38 \%$ & 892 & 558 \\
Lignite & 404 & $35 \%$ & 1,169 & \\
\hline
\end{tabular}

Of Germany's ten power stations with the highest $\mathrm{CO}_{2}$ emissions, nine use lignite [44]. The share of lignite in German electricity generation slightly increased after the first nuclear power plants were decommissioned, not least because of the low $\mathrm{CO}_{2}$ certificate price under the European Emissions Trading Scheme (EU-ETS) [44]. A letter from 80 municipal electricity companies expressed their support for the plans of the Federal Ministry for Economic Affairs and Energy for the climate levy. The letter referred to the pending structural change in the energy sector, as the $\mathrm{CO}_{2}$ reduction targets have been known for at least eight years. "The national and European climate protection targets can only be reached if, in addition to efficiency gains in the heating and transport sector, electricity generation in Germany is largely decarbonised by 2050" [45].

Despite this support, the lobby for lignite is strong. The original aim of the Ministry for Economic Affairs and Energy was to save 22 million tonnes of $\mathrm{CO}_{2}$ emissions but this target was subsequently reduced to 16 million tonnes. The remaining 6 million tonnes of $\mathrm{CO}_{2}$ emissions ought to be achieved using cogeneration power plants [46]. At the time of writing this paper, the responsible ministry is planning to mothball some lignite power plants (in total $2.7 \mathrm{GW}$ ) in order to keep them as a capacity reserve until 2020 [47], so instead of imposing an additional levy on these power plants-the government's original plan to help achieve international climate targets-the electricity companies now receive a cost-based compensation.

This example illustrates the broad support from different actors for Germany's most important fossil fuel domestic energy source. The fossil fuel divestment campaign is therefore facing resistance. NGOs, including Urgewald or Germanwatch, have faced similar obstacles in calling for a complete phase out of coal. That said, the transition of lignite power plants into a capacity reserve of limited duration can be viewed as a first step towards such a phase out.

\section{Conclusions}

In this paper we show that the current generation portfolios of the four largest German energy companies are heavily based on the fossil fuels gas, hard coal and lignite. E.ON's portfolio features $53 \%$ fossil fuels, RWE generates $76 \%$ of its energy from fossil fuels, Vattenfall $73 \%$ and EnBW 50\% (see Table 4). In particular, the high share of energy generation from lignite, which is considered the 
dirtiest fossil fuel, justifiably labels those companies as ideal targets for the divestment campaign. Furthermore, the companies' current business models do not seem fit for the pending challenge of climate change. Neither are they in line with the political agenda of the German government.

Table 4 lists the structure of the power plant capacity in MW in Germany.

Table 4. Power Plant Capacity of the four German companies [48-51].

\begin{tabular}{ccccc}
\hline & E.ON & RWE & Vattenfall & EnBW \\
\hline Gas & $3887(22 \%)$ & $4411(17 \%)$ & $1707(10 \%)$ & $1191(9 \%)$ \\
\hline Hard Coal & $4976(28 \%)$ & $5318(20 \%)$ & $2866(17 \%)$ & $4776(35 \%)$ \\
\hline Lignite & $500(3 \%)$ & $10,291(39 \%)$ & $7767(46 \%)$ & $875(6 \%)$ \\
Nuclear & $5403(30 \%)$ & $3908(15 \%)$ & $771(5 \%)$ & $3333(24 \%)$ \\
\hline Renewables * & $2104(12 \%)$ & $55(3,107 * *)(0.2 \%)$ & $124 * * *(1 \%)$ & $2632(19 \%)$ \\
\hline Pumped Storage, Oil, Other & $1136(6 \%)$ & $2537(10 \%)$ & $3511 * * * *(21 \%)$ & $941(7 \%)$ \\
\hline TOTAL & $18,006(100 \%)$ & $26,520(100 \%)$ & $16746(100 \%)$ & $13,748(100 \%)$ \\
\hline
\end{tabular}

* Comparatively high figures for E.ON and EnBW: E.ON only lists "Hydro", therefore these figures entail pumped-storage power plants as well; EnBW lists "Storage/pumped storage power plants using the natural flow of water" as Renewables; ** Renewables division, figure for whole RWE Group; *** Wind and Biomass (Waste); **** Hydro power amounts to 2,880 MW alone, which are mainly pumped-storage power plants.

Having said that, these companies have undertaken the first small steps to restructure: E.ON, for example, is now focussing on renewable energy while Vattenfall is selling lignite generation plants and mines in Eastern Germany. However, E.ON's restructure could mean it avoids liabilities should falling profits from fossil fuel and nuclear energy generation force its new company, Uniper, into insolvency. Under the E.ON brand, the company can focus on future-proofed renewable energy technologies but if the costs of decommissioning nuclear plants and nuclear waste management are excessive, Uniper could become insolvent leaving the German taxpayer to foot the bill.

In the most recent past, focussing on renewable energies has become an important business strategy. One indication is the establishment of new subsidiary companies by the four businesses examined here:

- E.ON Climate \& Renewables (2007),

- RWE Innogy (2008),

- Vattenfall Europe New Energy GmbH (2007),

- EnBW Renewable Energies (2008).

Furthermore, these companies invest in renewable energy technology every year as part of their overall investments as Tables 5-7 show.

Table 5. E.ON-overall investment and share of investment in renewables [48,52-56].

\begin{tabular}{ccc}
\hline Year & Investment (€ in millions) & Renewables \\
\hline $\mathbf{2 0 0 8}$ & 18,406 & $1484(8 \%)$ \\
$\mathbf{2 0 0 9}$ & 8655 & $1031(12 \%)$ \\
$\mathbf{2 0 1 0}$ & 8286 & $1163(14 \%)$ \\
$\mathbf{2 0 1 1}$ & 6524 & $1114(17 \%)$ \\
$\mathbf{2 0 1 2}$ & 6997 & $1791(26 \%)$ \\
$\mathbf{2 0 1 3}$ & 8086 & $1028(13 \%)$ \\
$\mathbf{2 0 1 4}$ & 4633 & $1222(26 \%)$ \\
\hline
\end{tabular}


Table 6. RWE-overall investment and share of investment in renewables [49,57-61].

\begin{tabular}{ccc}
\hline Year & Investment $(\boldsymbol{\epsilon}$ in Millions) & RWE Innogy \\
\hline $\mathbf{2 0 0 8}$ & 5693 & $1102(19 \%)$ \\
$\mathbf{2 0 0 9}$ & 15,637 & $733(5 \%)$ \\
$\mathbf{2 0 1 0}$ & 6643 & $709(11 \%)$ \\
$\mathbf{2 0 1 1}$ & 7702 & $891(12 \%)$ \\
$\mathbf{2 0 1 2}$ & 5544 & $1093(20 \%)$ \\
$\mathbf{2 0 1 3}$ & 4624 & $1083(23 \%)$ \\
$\mathbf{2 0 1 4}$ & 3440 & $738(21 \%)$ \\
\hline
\end{tabular}

Table 7. EnBW-overall investment and share of investment in renewables [51,62-64].

\begin{tabular}{ccc}
\hline Year & Investment $(\boldsymbol{\epsilon}$ in millions) & Renewable Investment EnBW \\
\hline $\mathbf{2 0 0 9}$ & 4374.1 & $153.7(4 \%)$ \\
$\mathbf{2 0 1 0}$ & 2327.9 & $536.4(23 \%)$ \\
$\mathbf{2 0 1 1}$ & 1319.0 & $216.6(16 \%)$ \\
$\mathbf{2 0 1 2}$ & 877.4 & $121.6(14 \%)$ \\
$\mathbf{2 0 1 3}$ & 1108.3 & $316.5(29 \%)$ \\
$\mathbf{2 0 1 4}$ & 1956.7 & $610.8(31 \%)$ \\
\hline
\end{tabular}

In the past, Vattenfall has formulated rolling investment plans for a five-year period. The company initially budgeted SEK 147 billion for the period 2012-2016 then in 2013 amended investment plans to SEK 105 billion for the period 2014-2018 [65]. More recently, as markets have become characterised by over-capacity in production and low prices, the company has decided to limit its most recent investment plan to two years (2015-2016) and to invest SEK 41 billion over that period, of which SEK 30.8 billion, or $75 \%$, will be invested in electricity and heat production. A large amount will be invested in wind energy (SEK 9.1 billion), whereas investments in fossil fuel production were determined several years ago under completely different market conditions [50]. The aim of the company is to reduce its $\mathrm{CO}_{2}$ exposure to 65 million tonnes of absolute emissions by 2020 (in 2014 the $\mathrm{CO}_{2}$ emissions amounted to 82.3 million tonnes, in 2010 they totalled 94 million tonnes). To achieve this target, the company has a two-part strategy: the divestment of fossil-based production and growth and investment in renewable production [50].

Even so, these figures somewhat pale in comparison to the total investment in renewable energies in Germany (see Figure 4). In fact, the lion's share of installed renewable capacity in Germany is not owned by the four energy giants. A study by Leuphana University of Luneburg, commissioned by the Agency for Renewable Energies [66], assessed the ownership structures of installed renewable energy production. Researchers concluded that the largest share $(47 \%)$ of installations was owned by 'citizen energy' (community or local ownership, citizen-owned power stations and sole proprietors). An equally impressive $41 \%$ share was owned by what the study called institutional and strategic investors-companies involved in industrial production processes or service providers. The study concluded that only $12 \%$ of installed renewable energy capacity was owned by energy suppliers, including the four companies examined in this paper. Figure 5 shows the distribution as put forward in the study. 


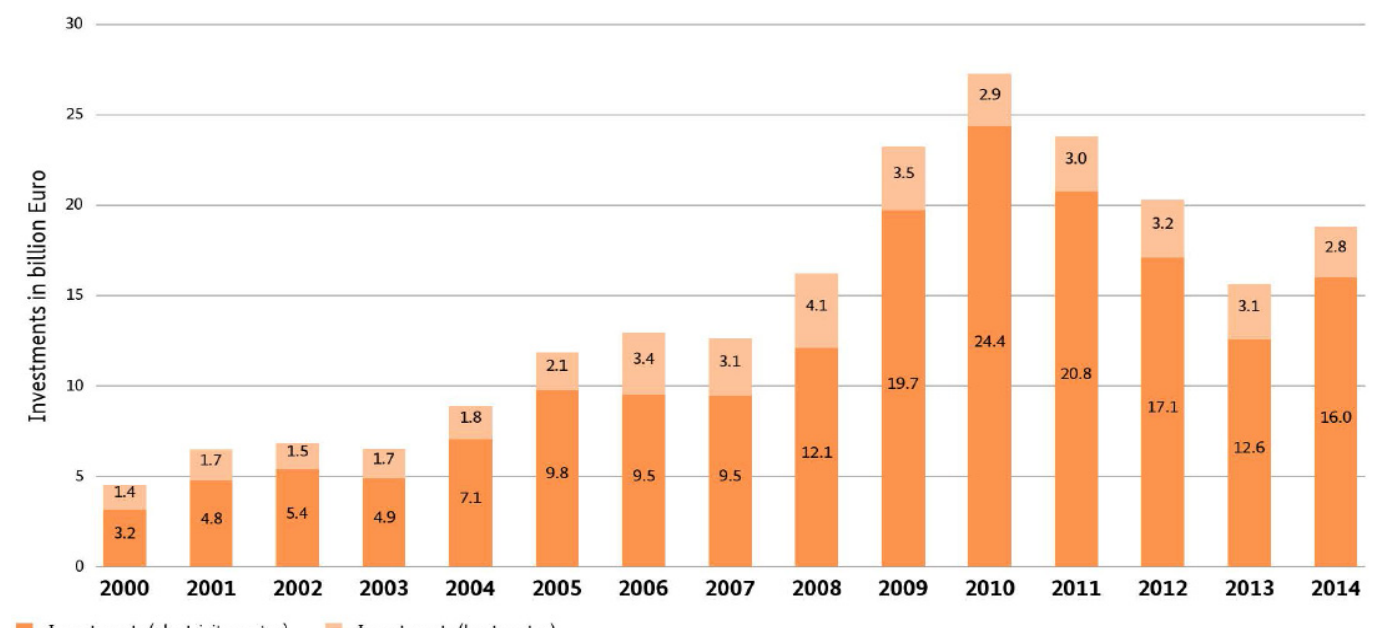

Figure 4. Development of investments in construction of renewable energy installations in Germany [20].

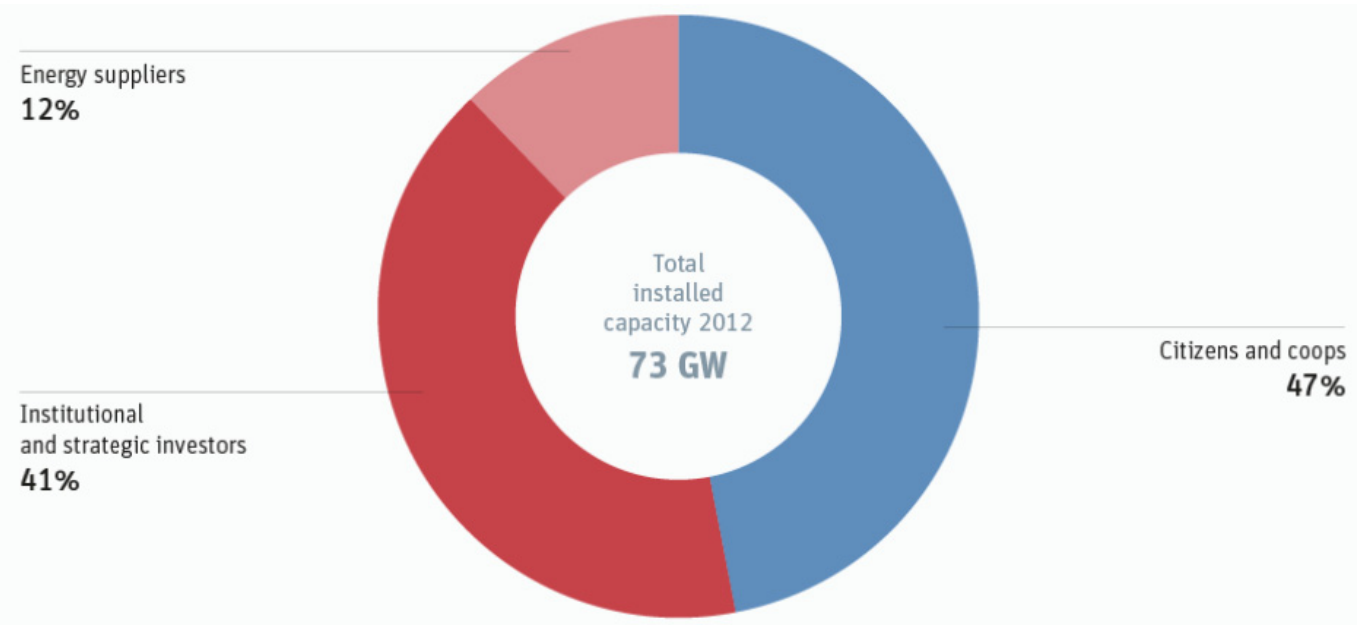

Figure 5. Installed capacity of renewable energies in Germany in 2012 as per property owner [29] * (* Coops stands for 'energy cooperatives': community-owned renewables projects).

The current business model featured by the four companies examined in this paper is often regarded as unsustainable and out of step with governmental climate targets. Furthermore, the carbon content of the companies' energy production is no longer only examined by governments and monitored by non-governmental organisations, but now also evaluated by the financial sector [6].

In 2003, the German WestLB, a former regional state bank, published a study with the title "Von Economics zu Carbonomics-Value at Risk durch Klimawandel" (From Economics to Carbonomics-Value at Risk caused by Climate Change) in which it analysed the response of the financial sector to expected climate regulation such as the Kyoto Protocol coming into force or the introduction of the European Emissions Trading Scheme (EU ETS). Organisations such as the Carbon Disclosure Project (CDP), which discloses the greenhouse gas emissions of major corporations, underline this interest. "When the financial services industry-which focuses like a laser on return on investment-starts worrying about the environment, something big is happening" [36].

In this paper, we have examined the influence of the fossil fuel divestment campaign on the four largest German electricity companies. We found that four entirely different influencers were more powerful in 
drawing attention to climate policies and their consequences at corporate board meetings than the aims of the divestment movement. These influencers were: electricity prices, company ownership, government regulation and domestic energy sources. We thus conclude that the campaign does not currently directly influence decision making at the German energy giants enough to alter the structure of the German electricity mix. Of course, our analysis provides only a snapshot and over time this campaign may well gain more influence in Germany. There is already some movement in the four big electricity companies towards renewable energy production. Up until a few years ago those companies were able to pursue their business model with fossil fuels and nuclear energy alone, despite Germany's strong civil movement which has been vociferously against nuclear energy. With the new social movement that is the fossil fuel divestment campaign another cause must be factored into company business decisions.

The possible influence the campaign actually has will depend on global climate policy. The consulting firm Mercer points out that: "It is clear from our survey that credible and consistent climate change legislation and regulation is required to drive greater integration of climate change into investment practices and to provide the major impetus for a shift from high carbon to low carbon investment. Without strong climate policy that provides transparency, longevity and clarity for investors, the revolution that is called for in transforming our energy systems will not be possible" [67]. A first step, a "golden opportunity", was described by the IMF's fiscal affairs head and former finance minister of Portugal, Vitor Gaspar [25]. He suggested taking advantage of low oil and coal prices and phasing out subsidies of global fossil fuels, which would reduce the global $\mathrm{CO}_{2}$ emissions by more than $20 \%$ [26].

\section{Acknowledgments}

We would like to thank Stefan Thomas (Wuppertal Institute) for providing feedback on an earlier draft. We are indebted to Gail Whiteman (Erasmus University Rotterdam) and David Deephouse (University of Alberta) who helped shape our ideas at various stages of this work. Furthermore, we would like to thank two anonymous reviewers for encouraging us to improve our manuscript. Any remaining errors are ours.

\section{Author Contributions}

Both authors designed the work, analysed the data and interpreted the results. Dagmar Kiyar planned and conducted the qualitative research. She also selected the quantitative secondary sources. Both authors contributed to and edited the manuscript.

\section{Conflicts of Interest}

The authors declare no conflict of interest.

\section{References}

1. E.ON Press release 04/27/15: E.ON moves forward with transformation: key organizational and personnel decisions made. Available online: http://www.eon.com/en/media/news/press-releases/ 2015/4/27/eon-moves-forward-with-transformation-key-organizational-and-personnel-decisionsmade.html (accessed on 15 July 2015). 
2. BMUB: Aktionsprogramm Klimaschutz 2020. Kabinettsbeschluss vom 3. Dezember 2014. Available online: http://www.bmub.bund.de/fileadmin/Daten_BMU/Download_PDF/ Aktionsprogramm_Klimaschutz/aktionsprogramm_klimaschutz_2020_broschuere_bf.pdf (accessed on 15 July 2015).

3. International Energy Agency (IEA). World Energy Outlook 2012; OECD: Paris, France, 2012.

4. McGlade, C.; Ekins, P. The geographical distribution of fossil fuels unused when limiting global warming to $2{ }^{\circ} \mathrm{C}$. Nature 2015, 517, 187-190.

5. Carbon Disclosure Project (CDP). Flicking the switch. Are electric utilities prepared for a low carbon future. May 2015. Available online: https://www.cdp.net/Docs/investor/2015/electricutilties-report-exec-summary-2015.pdf (accessed on 17 August 2015).

6. Kiyar, D. Um(welt)orientierung großer Energiekonzerne? Die großen Vier und ihr Beitrag zum Klimaschutz. Ph.D. Thesis, Westfälische Wilhelms-Universität Münster, Institut für Politikwissenschaft, Münster, 22 June 2012. http://repositorium.uni-muenster.de/document/miami/ 364834e7-9a8e-4ad8-ab4f-83feadd7e4ad/diss_kiyar_buchblock.pdf (accessed on 25 May 2015).

7. Bank of England. Confronting the challenges of tomorrow's world. Speech given by Paul Fisher, Deputy Head of the Prudential Regulation Authority and Executive Director, Insurance Supervision. Economist's Insurance Summit 2015, London. 3 March 2015. Available online: http://www.bankofengland.co.uk/publications/Documents/speeches/2015/speech804.pdf (accessed on 25 May 2015).

8. The Wall Street Journal. Norway Oil Fund Sheds More Coal Assets. 4 May 2015. Available online: http://www.wsj.com/articles/norway-oil-fund-sheds-more-coal-assets-1430765503 (accessed on 25 May 2015).

9. HSBC. Stranded assets: what next? How investors can manage increasing fossil fuel risks. 16 April 2015. Available online: http://www.businessgreen.com/digital_assets/8779/hsbc_Stranded _assets_what_next.pdf (accessed on 25 May 2015).

10. McKibben, B. Global Warming's Terrifying New Math. Rolling Stone. 19 July 2012. Available online: http://www.rollingstone.com/politics/news/global-warmings-terrifying-newmath-20120719 (accessed on 25 May 2015).

11. Ansar, A.; Caldecott, B.; Tilbury, J. Stranded assets and the fossil fuel divestment campaign: what does divestment mean for the valuation of fossil fuel assets? 2013. University of Oxford. Smith School Stranded Assets Programme. Available online: http://www.smithschool.ox.ac.uk/researchprogrammes/stranded-assets/SAP-divestment-report-final.pdf (accessed on 25 May 2015).

12. The Guardian. Climate change: UN backs fossil fuel divestment campaign. 15. March 2015. Available online: http://www.theguardian.com/environment/2015/mar/15/climate-change-unbacks-divestment-campaign-paris-summit-fossil-fuels (accessed on 25 May 2015).

13. UN. Ban Ki-moon urges more fossil fuel divestment. Statement 4. November 2014. Available online: http://newsroom.unfccc.int/financial-flows/ban-ki-moon-speaks-in-favour-of-divestment/ (accessed on 25 May 2015).

14. Devinney, T. The Guardian's fossil fuel divestment campaign could do more harm than good. 24 March 2015. Available online: http://theconversation.com/the-guardians-fossil-fueldivestment-campaign-could-do-more-harm-than-good-39000 (accessed on 25 May 2015). 
15. Fischer, W. No CCS in Germany Despite the CCS Act? In Carbon Capture, Storage and Use. Technical, Economic, Environmental and Societal Perspectives, 1st ed.; Kuckshinrichs, W., Hake, J.-F., Eds.; Springer: Heidelberg, Germany, 2015; pp. 255-286.

16. Pietzner, K.; Schwarz, A.; Duetschke, E.; Schumann, D. Media Coverage of Four Carbon Capture and Storage (CCS) Projects in Germany: Analysis of 1,115 Regional Newspaper Articles. Energy Procedia 2014, 63, 7141-7148.

17. RWE. Kraftwerksdaten 2015. 2. Quartal. Available online: http://www.rwe.com/web/cms/ mediablob/de/59784/data/59766/103/transparenz-offensive/deutschland/kraftwerksausfaelle/ Kraftwerksdaten-2015-Q2.pdf (accessed on 25 May 2015).

18. Bundesnetzagentur (BNetzA). Bescheid Transnet, Dezember 2013. Available online: http://www.bundesnetzagentur.de/SharedDocs/Downloads/DE/Sachgebiete/Energie/Unternehmen _Institutionen/Versorgungssicherheit/Erzeugungskapazitaeten/systemrelevante_KW/Bescheid_Tr ansnet_13_12_2013.pdf?_blob=publicationFile\&v=1 (accessed on 25 May 2015).

19. DG ENER. European Commission Quarterly Report on European Electricity Markets. Volume 7, Issue 4, Fourth quarter of 2014. Available online: https://ec.europa.eu/energy/sites/ener/files/documents/ quarterly_report_on_european_electricity_markets_2014_q4.pdf (accessed on 25 May 2015).

20. Federal Ministry for Economic Affairs and Energy (BMWi). Development of renewable energy sources in Germany 2014. Charts and figures based on statistical data from the Working Group on Renewable Energy-Statistics (AGEE-Stat), as at February 2015. Available online: http://www.erneuerbare-energien.de/EE/Redaktion/DE/Downloads/development-of-renewableenergy-sources-in-germany-2014.pdf?_blob=publicationFile\&v=6 (accessed on 25 May 2015).

21. Hauser, E.; Frantzen, J.; Leprich, U. Preissenkende Effekte der Solarstromerzeugung auf den Börsenstrompreis. Kurzstudie im Auftrag des Bundesverbandes Solarwirtschaft (BSW). Präsentation in Berlin, 31 January 2012. Available online: http:/www.solarwirtschaft.de/ fileadmin/media/pdf/120131_Präsentation_Preiseffekte_von_PV.pdf (accessed on 25 May 2015).

22. Fraunhofer Institute for Solar Energy Systems (ISE). Electricity Production and Spot-Prices in Germany 2014. 31 December 2014. Available online: http:/www.ise.fraunhofer.de/de/downloads/ pdf-files/data-nivc-/folien-electricity-spot-prices-and-production-data-in-germany-2014-engl.pdf (accessed on 16 July 2015).

23. DG ENER (2013). European Commission Quarterly Report on European Electricity Markets. Volume 6, Issue 2, Second quarter 2013. Available online: https://ec.europa.eu/energy/sites/ener/ files/documents/20130814_q2_quarterly_report_on_european_electricity_markets.pdf (accessed on 25 May 2015).

24. Fraunhofer Institute for Solar Energy Systems (ISE). Kohleverstromung zu Zeiten niedriger Börsenstrompreise. August 2013. Available online: http:/www.ise.fraunhofer.de/de/downloads/pdf-files/ aktuelles/kohleverstromung-zu-zeiten-niedriger-boersenstrompreise.pdf (accessed on 25 May 2015).

25. The Guardian. Fossil fuels subsidised by $\$ 10 \mathrm{~m}$ a minute, says IMF. 18 May 2015. Available online: http://www.theguardian.com/environment/2015/may/18/fossil-fuel-companiesgetting-10m-a-minute-in-subsidies-says-imf (accessed on 25 May 2015).

26. International Monetary Fund (IMF). How Large Are Global Energy Subsidies? IMF Working Paper WP/15/105. May 2015. Available online: http://www.imf.org/external/ pubs/ft/wp/2015/wp15105.pdf (accessed on 25 May 2015). 
27. Umweltbundesamt. Umweltschädliche Subventionen in Deutschland. Aktualisierte Ausgabe 2014. Available online: http://www.umweltbundesamt.de/sites/default/files/medien/376/publikationen/ umweltschaedliche_subventionen_in_deutschland_aktualisierte_ausgabe_2014_fachbroschuere.pdf (accessed on 15 July 2015).

28. Bundesnetzagentur. EEG-Umlage beträgt im kommenden Jahr 6,17 ct/kWh. Available online: http://www.bundesnetzagentur.de/SharedDocs/Pressemitteilungen/DE/2014/141014_PM_EEG_ Umlage.html (accessed on 15 July 2015).

29. Energy Transition. The German Energiewende. Available online: http://energytransition.de (accessed on 25 May 2015).

30. Federal Ministry for Economic Affairs and Energy (BMWi). 2014 Renewable Energy Sources Act: Plannable. Affordable. Efficient. Available online: http://www.bmwi.de/EN/Topics/Energy/ Renewable-Energy/2014-renewable-energy-sources-act,did=693154.html (accessed on 25 May 2015).

31. Gov.UK. Electricity Market Reform: Capacity Market. 24. July 2014. Last updated: 12. December 2014. Available online: https://www.gov.uk/government/collections/electricity-market-reformcapacity-market (accessed on 25 May 2015).

32. Federal Ministry for Economic Affairs and Energy (BMWi). An Electricity Market for Germany's Energy Transition. Discussion Paper of the Federal Ministry for Economic Affairs and Energy (Green Paper). Available online: http://www.bmwi.de/BMWi/Redaktion/PDF/G/gruenbuch-gesamtenglisch,property $=$ pdf,bereich $=$ bmwi2012, sprache $=\mathrm{de}, \mathrm{rwb}=$ true.pdf (accessed on 25 May 2015).

33. AG Energiebilanzen. Bruttostromerzeugung in Deutschland ab 1990 nach Energieträgern. February 2015. Available online: http://www.ag-energiebilanzen.de/index.php?article_id= 29\&fileName=20150227_brd_stromerzeugung1990-2014.pdf (accessed on 25 May 2015).

34. Labatt, S.; White, R.R. Carbon Finance. The Financial Implications of Climate Change; John Wiley \& Sons, Inc.: Hoboken, NJ, USA, 2007.

35. Roosevelt, T.; Llewellyn, J. Investors hunger for clean energy. Harvard Business Review 2007, $85,38-40$.

36. Esty, D.C.; Winston, A.S. Green to Gold. How Smart Companies Use Environmental Strategy to Innovate, Create Value, and Build Competitive Advantage; John Wiley \& Sons, Inc.: Hoboken, NJ, USA, 2009.

37. Schmidt, M.; Speich, I. Kritische Themen mit Unternehmen stärker diskutieren. Institutionelle Investoren hinterfragen immer mehr - Gut entwickelte Aufsichtsstrukturen stiften Anlegernutzen - Umwelt- und Sozialthemen integrieren. Börsen-Zeitung. Zeitung für Finanzmärkte. Sonderbeilage: Nachhaltigkeit 2011. Available online: https://www.boersen-zeitung.de/ index.php?li=1\&artid=2011045331\&titel=Kritische-Themen-mit-Unternehmen-staerker-diskutieren (accessed on 25 May 2015).

38. Schmidt, M.; Speich, I. Risikomanagement durch Nachhaltigkeit. Michael Schmidt und Ingo Speich bewerten das Engagement aktiver institutioneller Investoren. Deutsche Pensions- und Investmentnachrichten (dpn) 2011, 37-39. Available online: http://riskmanagementconference.com/docme/presse/292ab40c68ad0193a10e47ce9ce17881.0.0/Risikomanagement_dur ch_Nachhaltigkeit_DPN_0411.pdf (accessed on 25 May 2015).

39. Verband der kommunalen Aktionäre VKA. RW Energie-Beteiligungsgesellschaft mbH \& Co.KG. Available online: http://www.vka-rwe.de/index.php?id=4896 (accessed on 25 May 2015). 
40. Theurer, M.; Bünder, H. Größter Staatsfonds der Welt plant Kohle-Boykott. FAZ. 28 May 2015. Available online: http://www.faz.net/aktuell/wirtschaft/klimaschutz-groesster-staatsfonds-derwelt-plant-kohle-boykott-13617340.html (accessed on 25 May 2015).

41. Energy Intelligence. EI New Energy. Vol. IV, No. 15. 16 April 2015. Available online: http://www.smithschool.ox.ac.uk/research-programmes/stranded-assets/EI\%20New\%20Energy\% 20Apr\%2016.pdf (accessed on 25 May 2015).

42. DEBRIV. Aktuelle HWWI-Studie: Durch Sonderabgabe drohen massive Arbeitsplatzverluste in den Braunkohleregionen/ BMWi-Pläne gefährden alleine 40.000 Stellen in den Braunkohleregionen. April 2015. Available online: http://www.presseportal.de/pm/9341/2997191 (accessed on 25 May 2015).

43. Umweltbundesamt. Entwicklung der spezifischen Kohlendioxid-Emissionen des deutschen Strommix in den Jahren 1990 bis 2013. Climate Change 23/2014. Available online: http://www.umweltbundesamt.de/sites/default/files/medien/376/publikationen/climate_change_23 2014_komplett.pdf (accessed on 25 May 2015).

44. Öko-Institut. $\mathrm{CO}_{2}$-Emissionen aus der Kohleverstromung in Deutschland. March 2014. Available online: http://www.oeko.de/oekodoc/1995/2014-015-de.pdf (accessed on 25 May 2015).

45. Energie-Chronik. 80 Stadtwerke untertsützen Gabriels Pläne für eine Klimaabgabe. Available online: http://www.udo-leuschner.de/energie-chronik/150404d1.htm (accessed on 25 May 2015).

46. Reuters. Klima-Abgabe - Gabriel knickt bei Kohle-Plänen ein. Handelsblatt. 18 May 2015. Available online: http://www.handelsblatt.com/politik/deutschland/klima-abgabe-gabriel-knicktbei-kohle-plaenen-ein/11791272.html (accessed on 25 May 2015).

47. Federal Ministry for Economic Affairs and Energy (BMWi). July 2015. Eckpunkte für eine erfolgreiche Umsetzung der Energiewende. Politische Vereinbarungen der Parteivorsitzenden von CDU, CSU und SPD vom 1. Juli 2015. Available online: http://www.bmwi.de/BMWi/Redaktion/ $\mathrm{PDF} /$ E/eckpunkte-energiewende,property=pdf,bereich=bmwi2012,sprache=de,rwb=true.pdf (accessed on 17 August 2015).

48. E.ON. Annual Report 2014. Available online: http://www.eon.com/content/dam/eon-com/ueberuns/publications/150312_EON_Annual_Report_2014_EN.pdf (Accessed on 25 May 2015).

49. RWE. Annual Report 2014. March 2015. Available online: http://www.rwe.com/app/wartung/ hv2014/bpk_docs/RWE-Annual-Report-2014.pdf (accessed on 25 May 2015).

50. Vattenfall. Toward a more sustainable energy portfolio. Annual and sustainability report 2014. Available online: http:/corporate.vattenfall.com/globalassets/corporate/investors/annual_reports/ 2014/annual-and-sustainability-report-2014.pdf (accessed on 25 May 2015).

51. EnBW. Report 2014. Energiewende. Safe. Hands on. Available online: https://www.enbw.com/ enbw_com/downloadcenter/annual-reports/enbw-report-2014.pdf (accessed on 25 May 2015).

52. E.ON. E.ON Company Report 2008. Annual Report I/II. Available online: http://www.eon.com/ content/dam/eon-com/en/downloads/e/EON_Company_Report2008.pdf (accessed on 25 May 2015).

53. E.ON. E.ON AG Financial Statements pursuant to German GAAP and Combined Group Management Report for the 2010 Financial Year. Available online: http://www.eon.com/content/ dam/eon-com/en/downloads/e/E.ON_2010_Jahresabschluss_en_.pdf (accessed on 25 May 2015).

54. E.ON. Annual Report 2011. Available online: http://www.eon.com/content/dam/eon-com/en/ downloads/e/E.ON_2011_Annual_Report_pdf (accessed on 25 May 2015). 
55. E.ON. Annual Report 2012. Available online: http://www.eon.com/content/dam/eon-com/ ueber-uns/GB_2012_US_eon.pdf (accessed on 25 May 2015).

56. E.ON. Annual Report 2013. Available online: http://www.eon.com/content/dam/eon-com/ ueber-uns/publications/GB_2013_US_eon.pdf (accessed on 25 May 2015).

57. RWE. Annual Report 2009. Make big things happen. For our customers. Available online: http://www.rwe.com/web/cms/mediablob/en/575576/data/568444/3/rwe/investor-relations/agm/ annual-general-meeting-2010/annual-report-2009.pdf (accessed on 25 May 2015).

58. RWE. Annual Report 2010. RWE straight talking. Available online: http://www.rwe.com/web/ cms/mediablob/en/582360/data/609582/6/rwe/investor-relations/agm/annual-general-meeting-2011/ Annual-report-2010.pdf (accessed on 25 May 2015).

59. RWE. Annual Report 2011. Starting new chapters. Available online: http://www.rwe.com/web/ cms/mediablob/en/1338130/data/1310026/3/rwe/investor-relations/agm/annual-general-meeting-2012/ Annual-report-2011.pdf (accessed on 25 May 2015).

60. RWE. Annual Report 2012. Available online: http://www.rwe.com/web/cms/ mediablob/en/1802504/data/1798118/7/rwe/investor-relations/agm/annual-general-meeting-2013/ Annual-Report-of-RWE-AG-2012.pdf (accessed on 25 May 2015).

61. RWE. Annual Report 2013. Shaping the future. Available online: http://www.rwe.com/web/ cms/mediablob/en/1907134/data/1907462/5/rwe/investor-relations/agm/annual-general-meeting-2014/ Group-Annual-Report-2013.pdf (accessed on 25 May 2015).

62. EnBW. Annual Report 2010. Powered by diversity. Available online: https://www.enbw.com/media/ downloadcenter/annual-reports/annual-report-of-enbw-ag-2010.pdf (accessed on 25 May 2015).

63. EnBW. Annual Report 2011. Actively shaping the new energy concept. Available online: https://www.enbw.com/media/downloadcenter/annual-reports/annual-report-of-enbw-ag-2011.pdf (accessed on 25 May 2015).

64. EnBW. Report 2013. Energiewende. Safe. Hands on. Available online: https://www.enbw.com/ enbw_com/investoren/investors_docs/news_und_publikationen/enbw-report-2013-condensedversion.pdf (accessed on 25 May 2015).

65. Vattenfall. Annual Report 2011. Available online: https://www.vattenfall.com/en/file/2011_ Annual_Report.pdf_20332206.pdf (accessed on 25 May 2015).

66. Trend Research/ Leuphana Universität Lüneburg. Definition und Marktanalyse von Bürgerenergie in Deuschland. Im Auftrag der Initiative "Die Wende - Energie in Bürgerhand" und der Agentur für Erneuerbare Energien. Available online: http://100-prozent-erneuerbar.de/wp-content/uploads/2013/ 10/Definition-und-Marktanalyse-von-Bürgerenergie-in-Deutschland.pdf (accessed on 16 July 2015).

67. Mercer. Global Investor Survey on Climate Change - Annual Report on Actions and Progress 2010. June 2011. Available online: http://www.ceres.org/resources/reports/2010-global-investorsurvey-on-climate-change-1/view (accessed on 25 May 2015).

(C) 2015 by the authors; licensee MDPI, Basel, Switzerland. This article is an open access article distributed under the terms and conditions of the Creative Commons Attribution license (http://creativecommons.org/licenses/by/4.0/). 